\title{
Retraction Note: Poisson-type inequalities for growth properties of positive superharmonic functions
}

Kuan Luan ${ }^{1}$ and John Vieira ${ }^{2 *}$

The original article can be found online at https://doi.org/10.1186/ s13660-016-1278-7

"Correspondence: vieira.johnb@gmail.com

2Department of Matemática, Universidade Federal de Minas Gerais, Av Antonio Carlos 6627 Caixa Postal 702, Belo Horizonte, MG BR-31270901, Brazil

Full list of author information is available at the end of the article

\section{Retraction Note}

The Editors-in-Chief have retracted this article because it shows significant overlap with an article by different authors that was simultaneously under consideration with another journal [1]. The article also shows evidence of authorship manipulation and peer review manipulation. Additionally, the identity of the corresponding author could not be verified: Universidade Federal de Minas Gerais have confirmed that John Vieira has not been affiliated with their Department of Mathematics. The authors have not responded to correspondence regarding this retraction.

\section{Author details}

'Automation School, Harbin Engineering University, Harbin, 150001, China. ${ }^{2}$ Department of Matemática, Universidade Federal de Minas Gerais, Av Antonio Carlos 6627, Caixa Postal 702, Belo Horizonte, MG BR-31270901, Brazil.

\section{Publisher's Note}

Springer Nature remains neutral with regard to jurisdictional claims in published maps and institutional affiliations.

Published online: 31 August 2021

\section{References}

1. Lai, K., Mu, J., Wang, H.: New applications of Schrödingerean Green potential to boundary behaviors of superharmonic functions. Bound Value Probl 2017, 21 (2017). https://doi.org/10.1186/s13661-017-0746-4 (c) The Author(s) 2021. This article is licensed under a Creative Commons Attribution 4.0 International License which permits use sharing, adaptation, distribution and reproduction in any medium or format, as long as you give appropriate credit to the original author(s) and the source, provide a link to the Creative Commons licence, and indicate if changes were made. The images or other third party material in this article are included in the article's Creative Commons licence, unless indicated otherwise in a credit line to the material. If material is not included in the article's Creative Commons licence and your intended use is not permitted by statutory regulation or exceeds the permitted use, you will need to obtain permission directly from the copyright holder. To view a copy of this licence, visit http://creativecommons.org/licenses/by/4.0/. 